Originalartikkel

\title{
Trombolytisk behandling ved arterielt hjerneinfarkt hos barn
}

\author{
Sammendrag \\ Bakgrunn. Etter nyfødtperioden fore- \\ kommer arterielt hjerneinfarkt hos \\ barn med en insidens av 1-2/100 000 \\ barn/år. Trombolytisk behandling ved \\ hjerneinfarkt er nå anbefalt for voksne, \\ men er fortsatt omdiskutert behandling \\ for barn. Hensikten med denne artik- \\ kelen var å finne dokumentasjon for \\ trombolytisk behandling av hjerne- \\ infarkt hos barn.
}

\section{Materiale og metode. Artikkelen er basert på et ikke-systematisk littera- tursøk i PubMed og egne kliniske erfa- ringer fra behandling av unge voksne med hjerneinfarkt.}

Resultater. I den vestlige verden er hjertesykdom, kardiale intervensjonsprosedyrer og infeksjoner de viktigste årsaker til arterielt hjerneinfarkt hos barn. Barn med hjerneinfarkt bør initialt håndteres som voksne, med rask innleggelse og umiddelbar bildediagnostikk, fortrinnsvis magnettomografi med diffusjon og angiografi. Det finnes ingen randomiserte studier av trombolytisk behandling ved hjerneinfarkt hos barn. Den manglende dokumentasjonen gjør at denne behandlingsformen vanligvis ikke anbefales. Likevel blir den benyttet hos barn med hjerneinfarkt, og kasuistiske resultater foreligger.

Fortolkning. Ved akutte nevrologiske utfall som medfører fare for betydelig invaliditet, bør trombolytisk behandling overveies dersom alder yngre enn 18 år er eneste kontraindikasjon. Dersom trombolytisk behandling gis til barn med hjerneinfarkt, bør det registreres $i$ et internasjonalt register.

\section{Ulrike Waje-Andreassen}

ulrike.andreassen@helse-bergen.no

Lars Thomassen

Nevrologisk avdeling

Ånen Aarli

Barneklinikken

\section{Jostein Kråkenes}

Nevroradiologisk seksjon

Haukeland universitetssykehus 5053 Bergen

\section{Gunnar Norgård}

Barnehjerteseksjonen

Oslo universitetssykehus, Rikshospitalet og

Seksjon for pediatri

Institutt for klinisk medisin

Universitetet i Bergen

\section{David Russell}

Nevrologisk avdeling

Oslo universitetssykehus, Rikshospitalet

Arterielt hjerneinfarkt etter nyfødtperioden har en insidens på ca. 1-2/100 000 barn/år i Nord-Amerika, Europa og Australia (1, 2). Vi mangler data fra fattige og barnerike befolkningsgrupper i store deler av Afrika, Asia og Sør-Amerika. Rike strøk i Asia, som f.eks. Hongkong, har samme insidens som i vestlige land etter nyfødtperioden, men en større andel blødninger (3). En studie fra Riyadh i SaudiArabia viser sigdcelleanemi, genetiske sykdommer, infeksjoner som brucellose og revmatisk feber samt dehydrering som årsaker til hjerneinfarkt hos barn (4), årsaker som er uvanlige i vestlige land. Migrasjon av folkegrupper fører imidlertid til at sykdommer som sigdcelleanemi og andre hemoglobinopatier også ses i Norge (5). Artikkelen belyser aspekter ved diagnostikk og behandling av arterielt hjerneinfarkt hos barn med vekt på eksisterende viten om trombolyse. Trombolytisk behandling blir brukt hos barn, men er ikke godkjent behandling på grunn av manglende vitenskapelig dokumentasjon.

\section{Materiale og metode}

Artikkelen er basert på et ikke-systematisk litteratursøk i PubMed. I tillegg ble egen kjennskap til faglitteratur og erfaringer fra hjerneinfarktbehandling hos unge voksne inkludert. Artikkelens førsteforfatter har vært overlege på slagenheten på Nevrologisk avdeling, Haukeland universitetssykehus siden 2000 og har utført forskningsarbeid på unge pasienter med hjerneinfarkt. Avdelingen har behandlingsansvar for pasienter fra og med 15 års alder. Artikkelen omhandler barn i alderen 1 måned - 18 år.

\section{Etiologi og symptomer}

Hyppigste årsaker til hjerneinfarkt hos barn i Nord-Amerika, Europa og Australia er hjertesykdom og kardiale intervensjonsprosedyrer (ca. $25 \%$ ), infeksjoner og inflammasjonssykdommer (ca. 25\%) og ukjente årsaker (ca. 25\%) (6). Dette er i overensstemmelse med en norsk studie publisert i 2001 (7). Carotisdisseksjon og annen arteriesykdom, diabetes mellitus, familiær hyperkolesterolemi og andre metabolske sykdommer, hematologisk sykdom, malign sykdom, luft- og fettemboli er alternative årsaker til hjerneinfarkt hos barn (e-tab 1) (6).

Siden det blir flere med overvekt, diabetes mellitus, dyslipidemi og hypertensjon også i Norge, kan vi forvente noe økende insidens av hjerneinfarkt relatert til kardiovaskulær sykdom $(8,9)$. Sigdcelleanemi og moyamoya forekommer sjelden i Norge og har derfor tallmessig liten betydning for hjerneinfarkt her.

Som hos voksne er de fleste arterielle infarkter tromboemboliske og lokalisert i fremre kretsløp (arteria cerebri medias forsyningsområde), men i motsetning til hos voksne er lakunære infarkter hos barn sjeldne (10). Før ettårsalderen er epileptiske anfall og uspesifikke mentale forandringer hyppigere debutsymptomer enn fokale nevrologiske utfall $(46 \%)$. Etter ettårsalderen forekommer fokale nevrologiske utfall hyppigere $(78 \%)$ (11). Hovedsymptomer fra infarkter i fremre kretsløp er hemiparese, afasi, forandret men-

\section{Hovedbudskap}

- Arterielt hjerneinfarkt hos barn har en insidens på ca. 1-2 av 100000 barn per år

- Ca. 50 \% skyldes hjertesykdom og invasive hjerteprosedyrer eller infeksjoner og inflammasjon

- Kunnskap om trombolytisk behandling hos barn er begrenset, og randomiserte, kontrollerte studier mangler

- Trombolytisk behandling bør likevel vurderes ved akutt hjerneinfarkt hos barn

- Behandling bør registreres i et etablert internasjonalt register (IPSS) for prospektiv observasjon av effekt og sikkerhet 
tal funksjon og synsforstyrrelser. Hjerneinfarkt i bakre kretsløp kan fremkalle ustøhet, kvalme, oppkast, synsforstyrrelser, hemiparese, tetraparese og «locked in»-syndrom. Epileptiske anfall og akutt sterk hodepine kan være ledsagende symptomer ved akutt hjerneinfarkt og bør lede til rask reaksjon fra første legekontakt.

Hos barn utenfor sykehus er diagnosen hjerneslag meget sjelden, og sannsynligheten for at omsorgspersoner og helsepersonell får mistanke om hjerneslag er lav. En studie fra New York publisert i 2002 viste at blant 24 barn med en gjennomsnittsalder på 8-9 år var gjennomsnittlig tidsbruk fra symptomstart til første legekontakt 28 timer og gjennomsnittlig tidsbruk fra første legekontakt til diagnose sju timer (12). At det er forsinkelser utenfor og innenfor sykehus før diagnosen foreligger, er nylig blitt bekreftet av en større studie fra Toronto (13). Småbarn uten utviklet språk, funksjonshemmede eller febersyke barn med uttalte allmennsymptomer kan være spesielt vanskelig å diagnostisere.

\section{Diagnostikk}

Cerebral magnettomografi (MR) med diffusjonsvektet serie og angiografi foretrekkes for å unngå røntgenstråling og intravenøs kontrast. Differensialdiagnoser som hjerneblødning, sinusvenetrombose, fokal encefalitt, abscess eller hjernetumor vil være lettere å stille med MR enn med computertomografi (CT). Andre differensialdiagnoser som infeksjon, migreneanfall eller postiktal parese etter epileptisk anfall lar seg avklare ut fra anamnese, negativ MR og eventuell spinalpunksjon.

Ved akutte nevrologiske utfall hos barn og ungdom bør man mistenke hjerneinfarkt. Spesiell årvåkenhet bør utvises hos de minste, som ofte mangler fokale nevrologiske utfall. Siden omtrent halvparten av hjerneinfarktene hos barn oppstår i forbindelse sykehusopphold, bør helsepersonell utvise ekstra oppmerksomhet og reagere like raskt på mistanke som om det gjaldt en voksen. Komplikasjoner etter ukompliserte hjerteprosedyrer kan også oppstå de første dagene etter utskrivning fra sykehus, og alle endringer i tilstanden, som hvit og pulsløs ekstremitet, endring $\mathrm{i}$ bevissthet eller kramper, bør føre til rask innleggelse.

\section{Trombolytisk behandling}

Per i dag foreligger ingen randomiserte studier om trombolytisk behandling hos barn med hjerneinfarkt, og forfatterne kjenner ikke til at studier er planlagt eller påbegynt. Kunnskap er derfor hentet fra kasuistiske meddelelser og en nylig publisert oversiktsartikkel.

Årsaken til hjerneinfarktet har innflytelse på både behandlingseffekt og blødningsrisiko. Sigdcelleanemi kan føre til primær hjerneblødning og kan ved arterielt infarkt føre til sekundær hemoragisk transforma- sjon (2). Moyamoya kan disponere for blødninger (2), og ved sepsis og vaskulitter kan blødninger også lett oppstå. Ved disse grunnsykdommene er derfor trombolytisk behandling ikke anbefalt, og per i dag har man ikke erfaring på dette feltet. Unntaket er et nylig publisert enkelttilfelle der trombolytisk behandling ble gitt intraarterielt og uten blødningskomplikasjoner til en 12 år gammel jente med endokarditt og debut av afasi og høyre hemiparese (14). Selv om symptomene debuterte etter innleggelse, ble infarktforandringene bekreftet på MR først seks timer etter symptomdebut (14). Ti tross for allerede påvist endokarditt ble blødningsrisikoen hos denne pasienten vurdert som liten og den intraarterielle behandlingsprosedyren ble avsluttet åtte timer etter symptomdebut (14).

I en amerikansk studie fra 2007 ble det rapportert at $1,6 \%$ av barn med hjerneinfarkt fikk trombolytisk behandling (15) Studien var retrospektiv, og derfor var det mangelfull informasjon om alvorlighetsgraden før og etter trombolyse, doseringen av vevsplasminogenaktivator (tPA), tiden mellom symptomdebut og start av behandling og informasjon om hvilken arterieokklusjon som ble behandlet (16). De første trombolysene ble utført hos barn med okklusjon av a. basilaris, dvs. hos pasienter med potensiell stor invaliditet i form av «locked in»syndrom og høy mortalitet dersom tidlig rekanalisering ikke oppnås.

Fordi vi mangler sikker dokumentasjon for bruk av trombolytisk behandling hos barn med hjerneinfarkt, finnes ikke enhetlige retningslinjer for valg av medikament, dosering og prosedyre. Tabell 2 (17-24) og tabell 3 (24-33) gir en oversikt over barn med røntgenologisk påvist arterieokklusjon eller ferske arterielle infarkter som ble behandlet med trombolyse. Av tabellene fremgår det tydelig hvor stor variasjon det er $\mathrm{i}$ alle de aktuelle parametrene.

På grunn av liten fare for allergiske reaksjoner og kort halveringstid er tPA imidlertid blitt den dominerende substansen i trombolysebehandlingen for voksne og anbefales også for barn (34). The American Heart Association Stroke Council and the Council on Cardiovascular Disease in the Young (2) og aktuelle retningslinjer fra Chest (34) anbefaler at tPA kun blir brukt hos barn dersom de inkluderes i en studie. Man bør holde seg innenfor de anbefalte og godkjente tidsgrensene for voksne, det vil si tre timer for intravenøs trombolyse og seks timer ved intraarteriell trombolyse ved infarkter fremre kretsløp (2). Trombolytisk behandling hos voksne innen tre timer fra symptomstart ble godkjent i EU i 2002 (35). ECASS III-studien har nylig vist positiv effekt av intravenøs trombolyse hos voksne (18-80 år) også for behandlingsintervallet 3-4,5 timer (36). Dersom trombolytisk behandling overveies, bør tid fra symptomstart til behandling være kortest mulig innenfor disse tidsrammer ved iskemi i fremre kretsløp.

Det er ikke foretatt dosestudier av trombolytika hos barn. Kasuistiske meddelelser indikerer at den dose som benyttes hos voksne $(0,9 \mathrm{mg} / \mathrm{kg}$ kroppsvekt, $10 \%$ som bolus og $90 \%$ som infusjon over 60 minutter) også er trygg hos barn.

På grunn av lav insidens og problemer med å starte randomiserte studier hos barn med akutt arterielt hjerneinfarkt, har man valgt å starte en internasjonal observasjonsstudie, The International Pediatric Stroke Study (IPSS). De første data fra denne ble nylig publisert (37). 15 (2\%) av 687 barn fikk trombolyse (tPA), hvorav sju ble behandlet utenfor de anbefalte tidsvinduer for voksne (37). Fire av åtte barn behandlet innenfor de anbefalte tidsvinduene for voksne, utviklet asymptomatiske blødninger (37). To barn døde av store infarkter etter at trombolyse ikke førte til ønsket rekanalisering, fem barn forlot sykehuset med moderate eller alvorlige nevrologiske utfall, sju barn ble utskrevet uten eller med lette nevrologiske utfall og ett barn ble utskrevet uten opplysninger om tilstanden (37).

\section{Blødningskomplikasjoner}

Blødningskomplikasjoner ved trombolytisk behandling hos voksne er assosiert med økende alder og risikofaktorer som hypertensjon, diabetes og kroniske vaskulære forandringer som ses sjeldnere hos unge voksne (38). Vi ser ingen grunn til at blødningskomplikasjoner skulle være hyppigere hos barn enn hos unge voksne, spesielt dersom tidsgrenser overholdes.

Trombolytisk behandling av ikke-nevrovaskulær trombosering kan gi noe indikasjon på bivirkningsfrekvens med henblikk på systemiske blødningskomplikasjoner, inklusive hjerneblødninger. En komplikasjon etter hjertekateterisering hos barn er okklusjon av a. femoralis. En metaanalyse fra 1999 viste at vevsplasminogenaktivator (tPA) førte til komplett rekanalisering av a. femoralis hos 83 (93\%), mens lokale blødningskomplikasjoner ble registrert hos $29(33 \%)$ av 89 barn (39). Lokale blødningskomplikasjoner er imidlertid lett å kontrollere, og ingen av barna fikk større blødningskomplikasjoner med varig sekvele (39).

\section{Diskusjon}

Det finnes ikke systematiske data, større behandlingsserier eller randomiserte studier vedrørende trombolytisk behandling av barn med hjerneinfarkt. På grunn av lav insidens er det heller ikke sannsynlig at vi får tungt vitenskaplig kunnskapsgrunnlag for slik behandling de nærmeste årene. Diskusjon om trombolytisk behandling de siste årene har derfor vært basert på biologisk og patofysiologisk forståelse, nevrologiske erfaringer fra unge voksne pasienter og kasuistiske pediatriske meddelelser. 
En akutt tromboembolisk arterieokklusjon i hjernen har med overveiende sannsynlighet samme tidsavhengige katastrofale effekter på hjernevevet hos barn som hos voksne. Hos voksne har kun tidlig rekanaliserende behandling vist å kunne redusere akutt hjerneskade og nevrologiske senfølger, mens behandling med f.eks. platehemmere eller hepariner ikke har effekt (40). Det er ingen patofysiologiske mekanismer som skulle tilsi at forholdene er vesentlig annerledes hos barn hva angår rekanaliserende effekt av trombolyse. Det er derfor sannsynlig at trombolyse også vil ha klinisk effekt hos barn og at effekten vil være bedre jo tidligere behandlingen gis. Publiserte kasusbeskrivelser indikerer da også at trombolyse kan være nyttig hos barn med hjerneinfarkt. Sannsynligvis foreligger det en publikasjonsskjevhet i dette materialet, idet eventuelle alvorlige komplikasjoner med blødninger etter trombolytisk behandling neppe blir publisert i samme grad som positive resultater (41).

Trombolyse er ikke godkjent behandling av akutt hjerneinfarkt hos barn. Norsk barnelegeforening nevner trombolyse i sin akuttveileder fra 2007, men informerer samtidig om at denne behandlingsformen ikke er etablert hos barn. Det er anbefalt antikoagulasjon med lavmolekylært heparin som terapivalg. Denne behandlingen har man imidlertid sluttet med hos voksne etter flere studier som viser negativ effekt (40). I retningslinjene fra American Heart Association anbefales ikke trombolytisk behandling ved infarkt i neonatalperioden og heller ikke dersom barnet ikke inkluderes $\mathrm{i}$ en studie. Konsensus ble ikke nådd for de eldre ungdommene uten andre eksklusjonskriterier enn alderen (2).

\section{Konklusjon}

Vi mener at rask rekanalisering ved akutt okklusjon av store arterier og betydelige nevrologiske utfall bør være første behandlingsmål uansett alder. Blålysprioritering av pasienter med mistenkt hjerneinfarkt øker muligheten for tidlig diagnostikk og trombolyse med tidlig rekanalisering som mål. Ved mistanke om hjerneslag bør pediater eller nevrolog kontaktes for raskest diagnostisering og, dersom aktuelt, snarest mulig intravenøs eller intraarteriell trombolytisk behandling, mekanisk trombedestruksjon eller embolektomi. Behandling av arterielt hjerneinfarkt hos barn krever samarbeid mellom pediater, nevrolog, barnekardiolog og nevroradiolog. Per i dag må foreldrene til barnet gi sitt informerte samtykke til denne behandlingsformen.

Trombolyse ved arterielt hjerneinfarkt bør imidlertid ikke anvendes uten at pasienten er inkludert i en studie, og målet er at effekt og sikkerhet dokumenteres i IPSSregisteret (International Pediatric Stroke Study) (42). Det gir grunnlag for observasjonsstudier av barn som blir behandlet med trombolyse samt dokumentasjon av annen
Tabell 2 Trombolytisk behandling ved okklusjon av a. basilaris eller vertebralisdisseksjon hos barn. Tid = intervall fra symptomdebut til behandling, IA = intraarteriell, $\mathrm{tPA}=$ vevsplasminogenaktivator, PTA = ballongdilatasjon, $\mathrm{md}=$ måneder, $\mathrm{mRS}=$ modifisert Rankin-skala 10 = ingen nevrologiske utfall, 1 = lette utfall, klarer alle vanlige aktiviteter, 2 = utfall med begrensninger i aktiviteter, men fortsatt uavhengig av hjelp, $3=$ avhengig av hjelp fra annen person, $4=$ trenger mye hjelp men ikke permanent tilsyn, $5=$ pleiepasient, $6=\mathrm{d} ø$ d). Der mRS ikke ble angitt, ble den estimert av artikkelens førsteforfatter ut ifra informasjon etter mulig verste kategori

\begin{tabular}{|c|c|c|c|c|}
\hline År (ref.) & $\begin{array}{l}\text { Alder } \\
\text { (år) }\end{array}$ & Tid (timer) & Behandling & Resultat \\
\hline $1998(17)$ & 18 & 12 & IA 2,4 mill. U streptokinase & $\mathrm{mRS}=2$ etter $18 \mathrm{md}$ \\
\hline $2000(18)$ & 8 & 36 & IA PTA + $900000 \mathrm{U}$ urokinase & $\mathrm{mRS}=0$ etter $3 \mathrm{md}$ \\
\hline \multirow[t]{2}{*}{2003 (19) } & 9 & $<6$ & IA $750000 \mathrm{U}$ urokinase & $\mathrm{mRS}=0$ etter 4 dager \\
\hline & 10 & $<5$ & IA 1000000 U urokinase & $\begin{array}{l}\text { Mulig blødningskompli- } \\
\text { kasjon, mRS }=1 \text { etter } 6 \text { md }\end{array}$ \\
\hline $2003(20)$ & 15 & 60 & $\begin{array}{l}\text { IA mekanisk trombedestruk- } \\
\text { sjon + tPA } 0,1 \mathrm{mg} / \mathrm{kg}+\mathrm{PTA}\end{array}$ & $\mathrm{mRS}=0$ etter $12 \mathrm{md}$ \\
\hline $2003(21)$ & 18 & 72 & $\begin{array}{l}\text { IA tPA, doserings-informa- } \\
\text { sjon mangler }\end{array}$ & $\mathrm{mRS}=4$ etter $2 \mathrm{a} r$ \\
\hline 2007 (22) & 6 & 44 & IA $200000 \mathrm{U}$ urokinase & $\mathrm{mRS}=0$ etter $1 \mathrm{md}$ \\
\hline 2008 (23) & 3 & 18 & $\begin{array}{l}\text { IA } 3 \text { mg tPA, vektopplysninger } \\
\text { mangler }\end{array}$ & $m R S=2$ etter $6 \mathrm{md}$ \\
\hline $2009(24)$ & 9 & 12 & IA 750000 U urokinase & $\mathrm{mRS}=2$ etter $3 \mathrm{md}$ \\
\hline
\end{tabular}

akutt behandling for hjerneslag hos barn (37). For voksne fortsetter man arbeidet med å dokumentere effekt og sikkerhet av trombolyse i SITS-registeret (Safe Implementation of Thrombolysis in Stroke) (43).

Oppgitte interessekonflikter: Ulrike Waje-Andreassen har vært invitert til europeiske slagkongresser av firmaet Boehringer Ingelheim. Lars Thomassen har mottatt honorar fra Boehringer Ingelheim for diverse enkeltforelesninger. De

øvrige forfatterne har ingen oppgitte interessekonflikter.

e-tab 1 finnes i artikkelen på www.tidsskriftet.no

Litteratur

1. Simma B, Martin G, Muller T et al. Risk factors for pediatric stroke: consequences for therapy and quality of life. Pediatr Neurol 2007; 37: 121-6.

2. Roach ES, Golomb MR, Adams R et al. Management of stroke in infants and children: a scientific statement from a special writing group of the American Heart Association Stroke Council and

Tabell 3 Trombolytisk behandling ved okklusjon av a. carotis eller a. cerebri media hos barn. Tid = intervall fra sykdomsstart til behandling, IA = intraarteriell, IV = intravenøs, tPA = vevsplas minogenaktivator, VP = voksenprotokoll $(0,9 \mathrm{mg} / \mathrm{kg}: 10 \%$ bolus $+90 \%$ infusjon over 60 minutter $)$, $\mathrm{UK}=$ urokinase, $\mathrm{ACA}=$ arteria cerebri anterior, $\mathrm{ACM}=$ arteria cerebri media, $\mathrm{mRS}=$ modifisert Rankin-skala 10 = ingen nevrologiske utfall, 1 = lette utfall, klarer alle vanlige aktiviteter, 2 = utfall med begrensninger i aktiviteter, men fortsatt uavhengig av hjelp, 3 = avhengig av hjelp fra annen person, 4 = trenger mye hjelp, men ikke permanent tilsyn, $5=$ pleiepasient, $6=\mathrm{d} ø \mathrm{~d}$ ). Der $\mathrm{mRS}$ ikke ble angitt, ble den estimert av artikkelens førsteforfatter ut ifra informasjon etter mulig verste kategori

\begin{tabular}{|c|c|c|c|c|}
\hline År (ref.) & $\begin{array}{c}\text { Alder } \\
\text { (år) }\end{array}$ & Tid (timer) & Behandling & Resultat \\
\hline 2000 (25) & 6 & 2,0 & IA tPA 0,11 mg/kg & $\mathrm{mRS}=2$ etter 2 uker \\
\hline $2001(26)$ & 16 & $<3,0$ & IV tPA VP & $\mathrm{mRS}=2$ etter $2 \mathrm{md}$ \\
\hline 2001 (27) & 12 & 2,5 & IV tPA VP & $\mathrm{mRS}=0$ etter dag 2 \\
\hline $2001(28)$ & 13 & $<3,0$ & IV tPA 0,53 mg/kg, ellers VP & $\mathrm{mRS}=1$ etter $5 \mathrm{md}$ \\
\hline 2005 (29) & 15 & $<6$ & IA 560000 U UK & $\begin{array}{l}\text { Asymptomatisk blødnings- } \\
\text { komplikasjon, mRS = } 3 \text { etter } \\
1 \text { år og } 2 \text { md }\end{array}$ \\
\hline $2006(30)$ & 16 & 2,7 & IV tPA VP & $\mathrm{mRS}=1$ etter 8 timer \\
\hline 2007 (31) & 2 & 5,5 & $\begin{array}{l}\text { IA tPA } 0,53 \mathrm{mg} / \mathrm{kg} \\
0,35 \mathrm{mg} / \mathrm{kg} \text { i ACA } \\
0,18 \mathrm{mg} / \mathrm{kg} \text { i ACM }\end{array}$ & $\mathrm{mRS}=2$ etter 2 år \\
\hline 2007 (32) & 8 & 2,0 & IV tPA VP & $\mathrm{mRS}=2$ etter 3 uker \\
\hline 2008 (33) & 15 & $<2,0$ & IV tPA VP & $\mathrm{mRS}=1$ etter $5 \mathrm{md}$ \\
\hline 2009 (24) & 12 & 5 & IA 750000 U UK & $\begin{array}{l}\mathrm{mRS}=6 \text { dag } 2 \text {, d } \varnothing \mathrm{d} \text { etter } \\
\text { manglende rekanalisering } \\
\text { og malignt } \varnothing \text { dem }\end{array}$ \\
\hline
\end{tabular}


the Council on Cardiovascular Disease in the Young. Stroke 2008; 39: 2644-91.

3. Chung B, Wong V. Pediatric stroke among Hong Kong Chinese subjects. Pediatrics 2004; 114: e206-12.

4. Salih MA, Abdel-Gader AG. Diagnostic approach and management strategy of childhood stroke. Saudi Med J 2006; 27 (suppl 1): S4-11.

5. Lilleholt K, Hallberg MH, Hagve TA. Hemoglobinopatier og fremmedartede navn. Tidsskr Nor Lægeforen 2005; 125: $1164-7$.

6. Johnston MV, Comi A. Acute stroke syndromes. I: Kliegman RM, Jensom HB, Behrman RE et al, red. Nelson textbook of pediatrics. 18. utg. Oxford: WB Saunders, 2007: 2508-12.

7. Bjornstad A, Skjeldal OH. Iskemiske hjerneslag hos barn - en diagnostisk utfordring. Tidsskr Nor Lægeforen 2001; 121: 1826-8.

8. Narayan KM, Gregg EW, Fagot-Campagna A et al. Diabetes - a common, growing, serious, costly, and potentially preventable public health problem. Diabetes Res Clin Pract 2000; 50 (suppl 2): S77-84.

9. Joner G. Sovik O. The incidence of type 1 linsulindependent) diabetes mellitus 15-29 years in Norway 1978-1982. Diabetologia 1991; 34: 271-4.

10. Williams LS, Garg BP, Cohen M et al. Subtypes of ischemic stroke in children and young adults. Neurology 1997; 49: $1541-5$

11. Zimmer JA, Garg BP. Williams LS et al. Age-related variation in presenting signs of childhood arterial ischemic stroke. Pediatr Neurol 2007; 37; $171-5$.

12. Gabis LV, Yangala R, Lenn NJ. Time lag to diagnosis of stroke in children. Pediatrics 2002; 110: 924-8.

13. Rafay MF, Pontigon AM, Chiang J et al. Delay to diagnosis in acute pediatric arterial ischemic stroke. Stroke 2009; 40: 58-64.

14. Tan M, Armstrong D, Birken C et al. Bacterial endocarditis in a child presenting with acute arterial ischemic stroke: should thrombolytic therapy be absolutely contraindicated? Dev Med Child Neurol 2009: 51: 151-4.

15. Janjua N, Nasar A, Lynch JK et al. Thrombolysis for ischemic stroke in children: data from the nationwide inpatient sample. Stroke 2007; 38: 1850-4.

16. Belvis R. Thrombolysis for acute stroke in pediatrics. Stroke 2007; 38: 1722-3.

17. Larner AJ. Basilar artery occlusion associated with pathological crying: «folles larmes prodromiques»? Neurology 1998; 51: $916-7$.
18. Cognard C, Weill A, Lindgren S et al. Basilar artery occlusion in a child: «clot angioplasty» followed by thrombolysis. Childs Nerv Syst 2000; 16: 496-500.

19. Sungarian A, Duncan JA 3rd. Vertebrobasilar thrombosis in children: report of two cases and recommendations for treatment. Pediatr Neurosurg 2003; 38: 16-20.

20. Kirton A, Wong JH, Mah J et al. Successful endovascular therapy for acute basilar thrombosis in an adolescent. Pediatrics 2003; 112: e248-51.

21. Rosman NP, Adhami S, Mannheim GB et al. Basilar artery occlusion in children: misleading presentations, «locked-in» state, and diagnostic importance of accompanying vertebral artery occlusion. J Child Neurol 2003; 18: 450-62.

22. Grigoriadis S, Gomori JM, Grigoriadis N et al. Clinically successful late recanalization of basilar artery occlusion in childhood: what are the odds? Case report and review of the literature. J Neurol Sci 2007; 260: 256-60.

23. Bhatt A, Naravetla B, Majid A et al. Treatment of a basilar artery occlusion with intra-arterial thrombolysis in a 3-year-old girl. Neurocrit Care 2008: 9: 357-60

24. Arnold M, Steinlin M, Baumann A et al. Thrombolysis in childhood stroke: report of 2 cases and review of the literature Stroke 2009. 40:801-7.

25. Gruber A, Nasel C, Lang W et al. Intra-arterial thrombolysis for the treatment of perioperative childhood cardioembolic stroke. Neurology 2000; 54: $1684-6$.

26. Noser EA, Felberg RA, Alexandrov AV. Thrombolytic therapy in an adolescent ischemic stroke. J Child Neurol 2001; 16: 286-8

27. Cannon BC, Kertesz NJ, Friedman RA et al. Use of tissue plasminogen activator in a stroke after radiofrequency ablation of a left-sided accessory pathway. J Cardiovasc Electrophysiol 2001; 12: 723-5.

28. Carlson MD, Leber S, Deveikis J et al. Successful use of rt-PA in pediatric stroke. Neurology 2001, 57: 157-8.

29. Bourekas EC, Slivka AP, Casavant MJ. Intra-arter Ial thrombolysis of a distal internal carotid artery occlusion in an adolescent. Neurocrit Care 2005; 2: $179-82$.

30. Shuayto MI, Lopez JI, Greiner F. Administration of intravenous tissue plasminogen activator in a pediatric patient with acute ischemic stroke. J Child Neurol 2006; 21: 604-6.
31. Benedict SL, Ni OK Schloesser P et al Intraarterial thrombolysis in a 2-year-old with cardioembolic stroke. J Child Neurol 2007; 22: 225-7.

32. Ortiz GA, Koch $\mathrm{S}$, Wallace DM et al. Successful intravenous thrombolysis for acute stroke in a child. J Child Neurol 2007; 22: 749-52.

33. Jain SV, Morton LD. Ischemic stroke and excellen recovery after administration of intravenous tissue plasminogen activator. Pediatr Neurol 2008; 38: $126-9$

34. Monagle $\mathrm{P}$, Chalmers E, Chan A et al. Antithrombotic therapy in neonates and children: American College of Chest Physicians evidence-based clinical practice guidelines (8th edition). Chest 2008; 133 (suppl 6): 887-968S

35. Wahlgren N, Ahmed N, Davalos A et al. Thrombolysis with alteplase for acute ischaemic stroke in the Safe Implementation of Thrombolysis in Stroke-Monitoring Study (SITS-MOST): an observational study. Lancet 2007; 369: 275-82.

36. Hacke W, Kaste M, Bluhmki E et al. Thrombolysis with alteplase 3 to 4.5 hours after acute ischemic stroke. N Engl J Med 2008; 359: 1317-29.

37. Amlie-Lefond C, Deveber G, Chan AK et al. Use of alteplase in childhood arterial ischaemic stroke a multicentre, observational, cohort study. Lancet Neurol 2009; 8: 530-6.

38. Derex L, Nighoghossian N. Intracerebral haemorrhage after thrombolysis for acute ischaemic stroke: an update. J Neurol Neurosurg Psychiatry 2008; 79: 1093-9.

39. Chalmers EA, Gibson BE. Thrombolytic therapy in the management of paediatric thromboembolic disease. Br J Haematol 1999; 104: 14-21.

40. Berge E, Sandercock P. Anticoagulants versus antiplatelet agents for acute ischaemic stroke. Cochrane Database Syst Rev 2002; nr. 4: CD003242.

41. Braun KP, van der Worp HB. Thrombolysis in childhood ischaemic stroke: still a bridge too far. Lancet Neurol 2009: 8: 503-5.

42. Amlie-Lefond C. International Pediatric Stroke Study (IPSS). https://app3.ccb.sickkids.ca/cstrokestudy (2.6.2009)

43. Wahlgren NG. SITS Thrombolysis registry. www.acutestroke.org (2.6.2009).

Manuskriptet ble mottatt 17.1. 2009 og godkjent 10.9. 2009. Medisinsk redaktør Anne Kveim Lie. 